\title{
Some Tax Problems of Students and Scholars
}

\author{
H. Helmut Loring*
}

The sympathetic consideration shown recently by the Tax Court to tiger-hunting dairy executives ${ }^{1}$ would seem an appropriate starting point for an investigation of the attitude of our federal revenue laws toward endeavors which have a far greater impact on the course of our nation than Madison Avenue safaris.

This Article will deal with three areas of application of the Internal Revenue Code of 1954 which affect particularly the scholar, the scientist, and the advanced student preparing for an academic career: The tax treatment of educational and research expenses, of awards and prizes made in recognition of scholastic or scientific achievements, and of scholarships and fellowships. The group whose special tax problems are discussed here is numerically small and has little voice in the legislative process which produces our revenue laws. The relative scarcity of case law would also indicate that its members do not of ten have the financial resources necessary to litigate their tax problems and the deficiency amounts involved would normally be relatively small. The Treasury ought to be aware of both these factors in preparing its regulations and rulings.

\section{TAX TREATMENT OF EDUCATIONAL EXPENSES}

The Internal Revenue Code of 1954 has attempted no statutory clarification of the problems relating to the deductibility of educational expenses. Questions in this regard must be answered by reference to the general provision contained in section $162(a)$ as they were formerly answered by reference to section 23(a) (1) (A) of the 1939 Code and the case law interpreting that section. The question remains whether a particular outlay for educational purposes is a "necessary and ordinary" expense of a trade or business and therefore deductible, or whether it is considered either personal or a non-amortizable capital expense and therefore demied deduction. The importance of this problem is today at least reflected in the more elaborate treatment by the regulations. ${ }^{2}$

Given the framework of the code provision relating to the deductibility of business expenses, we have it on the authority of Justice Cardozo that

* Member, Oakland Bar.

${ }^{1}$ See Sanitary Farms Dairy, Inc. v. Commissioner, 25 T.C. 463 (1955).

2 See U.S. Treas. Proposed Reg. § 1.162-5. The regulations under the 1939 Code, U.S. Treas. Reg. 118, § 39.23(a)-15(f) merely mentioned that "expenses of taking special courses or training" were among those non-deductible. 
"reputation and learning are akm to capital assets"; that "the money spent in acquiring them is well spent," but that "it is not an ordinary expense of the operation of a business." 3

Thus under the general rule, all expenses incurred in preparation for a career in life, or to better one's position, learning or reputation, are deemed to be of the non-deductible type. ${ }^{4}$

In only two areas have taxpayers been successful in their attempts to deduct educational expenditures, and their success is now reflected in the proposed regulations under the 1954 Code. ${ }^{5}$ Where under state law teachers are required to take certain courses or undertake travel in order to retain their teaching qualifications or credentials, the expenses incurred in such travel, or for tuition, residence at a university, books and similar items have been held deductible. ${ }^{b}$ Similarly, expenses of attending refresher courses by persons engaged in a profession have been held deductible because incurred merely to keep proficient in a profession already acquired and not for the purpose of achieving a new status or position.

This Article is primarily concerned with the problems of persons whose educational and research expenses do not fit within either of the two areas where deductibility has been conceded. Two recent cases show that such persons have been unsuccessful in their attempts to have expenditures incurred in obtaining advanced degrees sufficiently connected with the maintenance of a present position so as to assure deductibility. In Kamins $v$. Commissioner ${ }^{8}$ and in Marlor v. Commissioner ${ }^{9}$ the taxpayers held temporary teaching positions at umiversities prior to the completion of the

3 Welch v. Helvering, 290 U.S. 111, 115-16 (1933). There is no doubt that Justice Cardozo thought such expenses to be necessary. "For many," he said, "they are the only tools with which to hue a pathway to success." Ibid.

4 The proposed regulations, $\S 1.162-5$ (a) (2), provide that "Expenditures for education which are made primarily for the purpose of, or which have the result of, obtaining a position for the taxpayer; qualifying him to enter an employment or otherwise become established in a trade or busmess or a specialty therem; establishing or enhancing substantially his reputation in his trade or business; substantially advancing him in earning capacity, salary, status or position; or primarily fulfilling the general cultural aspirations or other personal purposes of the taxpayer are personal expenditures and are not deductible." See Marlor v. Coinmissioner, 27 T.C. No. 70 (Dec. 26, 1956) ; Kamins v. Commissioner, 25 T.C. 1238 (1956); Larson v. Commissioner, 15 T.C. 956 (1950); Marshall v. Commissioner, 14 CCH Tax Ct. Mem. 955 (1955); Lampkin v. Commissioner, 11 CCH Tax Ct. Mem. 576 (1952).

5 U.S. Treas. Proposed Reg. $\$ \$ 1.162-5$ (c), (d).

${ }^{8}$ Hill v. Commissioner, 181 F.2d 906 (4th Cir. 1950); Fennelly v. Commissioner, 12 CCH Tax Ct. Mem. 489 (1953) ; I.T. 4044, 1951-1 Cum. BuLs. 16; I.T. 3380, 1940-1 Cusr. BuLx. 29; cf. Thompson v. Commissioner, 5 CCH 1957 Stand. Fed. Tax Rep. (1957-62 Tax Ct. Mem.) II 7419(M) (Mar. 29, 1957).

7 Coughlin v. Commissioner, 203 F.2d 307 (2d Cir. 1953); Bistline v. United States, 145 F. Supp. 802 (D. Idaho, 1956).

825 T.C. 1238 (1956).

${ }_{2} 27$ T.C. No. 70 (Dec. 26, 1956). 
requirements for the Ph.D. degree in their fields. In both cases these taxpayers could retain their position only by diligently working toward the acquisition of the degree and by ultimately obtaining it. ${ }^{10}$ Yet in both cases the expenses incurred in meeting the requirements for the doctoral degree were denied deductibility on the theory that these expenses were still part of the cost of general preparation for an academic career and therefore not the type of expenditure which is incurred to maintain a position already securely acquired. The reasoning seems to be that these expenses are in the nature of non-amortizable capital expenditures. This reasoning is sound since the distinction between the teaching assistant or instructor who has yet to obtain his final degree to qualify for a permament academic career and the teacher who periodically must attend special courses to retain his teaching credential is quite realistic. ${ }^{11}$

But the true distinction lies in the nature of the expenditure, capital in the former case, current and ordinary in the second, and not in the absence or presence of any state law requiring the particular expense. Any rule imposing a test whereby such educational expenses are deemed necessary and ordinary only if required by some state $\mathrm{law}^{12}$ would not only be grossly unfair but also quite untenable unless the statutory terms do not mean the same thing for the scholar as they do for the businessman. Two exaniples will illustrate the problem. Mr. $\mathrm{X}$ and $\mathrm{Mr}$. $\mathrm{Y}$ are professors of political science. Froin what little authority there is we may assume that they can deduct their membership fees in professional societies, the cost of subscriptions to journals in their fields, and the cost of attending meetings of such groups as the American Political Science Association. They can also amortize the cost of learned treatises in their field. ${ }^{13}$

Mr. X specializes in the Western European area and uses his sabbatical leave for a trip to Europe during which he collects material for publication and for enriching his lectures with his personal experience. Undoubtedly he will engage in sonie sightseeing along the way, but his travel schedule clearly shows that the main purpose of the trip is directly connected with his special field of study. Mr. $Y$ is engaged in different research and soon discovers that the material available at the library of his own umiversity is inadequate. He is informed that the materials are available at the hibrary

10 In the Kamins case this condition was set forth in a formal communication to the taxpayer fron the dean; In the Marlor case the conditions were contained in sections 112 and $131(B)$ of the by-laws of the New York Board of Higher Education and thus were part of the applicable state law.

11 Yet three Tax Court judges dissented in the Marlor case because they could not distinguish the facts from those of Hill v. Commissioner, 181 F.2d 906 (4th Cir. 1950). See 27 T.C. No. 70 at p. 3 (Dec. 26, 1956).

12 It slould he noted that this test is not even applied where refresher course expenses of professional people are involved. See text at note 7 supra.

13 U.S. Treas. Proposed Reg. \$ 1.162-6; cf. I.T. 3448, 1941-1 Cusr. Buxx. 206. 
of a university in another part of the country where Mr. Y therefore spends his summer, incurring the expenses of the travel and of his stay while completing his research. Are $\mathrm{X}$ and $\mathrm{Y}$ entitled to deduct the expenses incurred in their scholarly enterprises?

In Cardozo v. Commissioner ${ }^{14}$ the Tax Court denied the deduction of expenses incurred on a trip to Europe by a professor of Romance languages. Beyond a mere statement by the court that the trip was undertaken "for the purpose of research and study"15 there is no mdication of what was done during the sojourn in Europe and whether the places and persons visited show a close relation to the taxpayer's special field. The main argument of the court was that since nothing in the university regulations required a professor to take such trips to maintain his present position, the expenses incurred were not necessary to the taxpayer's trade or business. ${ }^{16}$

Similarly, a ruling of the Treasury Department takes the position that the expenses of an instructor at a private secondary school on a study trip abroad are personal and therefore non-deductible. ${ }^{17}$

It is submitted that the statutory term "necessary" is misconstrued in both the Cardozo case and the Revenue Ruling just mentioned. In determining whether the expenses of a businessman are deductible, the courts have never considered whether or not a particular business expense was required by any state law or trade regulation. In Welch $v$. Helvering ${ }^{18} \mathrm{Jus}-$ tice Cardozo indicated that whether an expenditure is necessary is foremost a question to be answered by the taxpayer who incurs the expense and his judgment should not easily be discarded by the courts. ${ }^{10}$ The term has never been interpreted to mean legal or absolute necessity, but rather has been taken to require that the expense be reasonably appropriate and helpful to the taxpayer's busmess. ${ }^{20}$ If it is necessary in that sense, the expense cannot be a personal one. This is the test which should have been applied in Car-

1417 T.C. 3 (1951).

$15 \mathrm{Id}$. at 4 .

16 Id. at 5-6. The court conceded arguendo that the expenses might have been ordinary. Ibid.

17 Rev. Rul. 55-412, 1955-1 Cun. Burc. 318. This ruling points out that the travel was not required by the school as a condition for retaining employment with it and the expenses were therefore deemed personal. Yet the facts show that the school thought such travel abroad sufficiently important for its teachers that it granted thein leave with pay for that purpose.

18290 U.S. 111, 113 (1933).

10 See also 4 Mertens, Federal Incone Taxation, $\$ 25.09$ (rev. ed. 1954) and authoritics collected therein.

20 See, e.g., Commissioner v. Pacific Mills, 207 F.2d 177, 180, 181 (1st Cir. 1953). And see Waring Products Corp. v. Commissioner, 27 T.C. No. 114, at ....... (1957): "We know of no requirement that there must be an underlying legal obligation to make an expenditure before it can qualify as an 'ordinary and necessary' busimess expense under Section 23 (a), Internal Revenue Code of 1939. The basic question is whether, in all the circumstances, the expenditure is ordinary and appropriate to the conduct of the taxpayer's business." 
dozo v. Commissioner and in the Revenue Ruling. ${ }^{21}$ If that test was met, the result reached in these cases is erroneous.

Under the same test our suppositious professors, $\mathrm{X}$ and $\mathrm{Y}$, must be allowed to deduct their respective expenses. Since they deeined them necessary in their profession, or they would not have incurred them, why should their judgment as to the necessity of the expenses not prevail? Independent research is an integral part of the curriculum in any advanced field of learning. Any teacher on the graduate level of education is measured in his effectiveness only partly by his class-room technique. His attainments in research are given at least equal weight. ${ }^{22}$ In other words, his profession is both the imparting of old and the acquisition of new knowledge. Expenses incurred in the latter pursuit are just as necessary as those incurred in the former.

Little needs to be said on the question whether these expenses are also "ordinary" within the meaning of the statute. In the experience of the group with which we here deal such expenses are a normal and recurring incident of their chosen profession and this is the decisive test. ${ }^{23}$

It is therefore submitted that the decision in Cardozo v. Commissioner is in error if there was a sufficient factual showing that the travel purpose related to the special field of the taxpayer's study. On the facts presented by the Revenue Ruling ${ }^{24}$ the opinion of the Treasury may be correct only on the theory that a study trip abroad, even though deemed necessary by the employing secondary school to the extent of giving leave with pay for that purpose, is not a normal and recurring expense for a secondary school teacher and therefore not ordinary within the meaning of the statute. In the examples posed as to $\mathrm{X}$ and $\mathrm{Y}$, the deductibility of the expenses should be beyond doubt.

\section{PRIZES AND AWARDS}

The tax treatment of prizes and awards is regulated by statute for the first time by section 74 of the Internal Revenue Code of 1954 . As the senate committee report shows, a statutory regulation was deemed necessary because of certain decisions which held prizes awarded in a contest to be nontaxable gifts rather than taxable income. ${ }^{25}$

21 See text following note 14 supra.

22 Cf. Parker, The Good Law School: Pipedreams of a Lawyer from Two Continents, 42 A.B.A.J. 1123 (1956). The author points out that on the Continent the calibre of a law professor is measured alnost entirely by the research and writing he has done, not by his teaching performance.

23 Welch v. Helvering, 290 U.S. 111, 114 (1933); Deputy v. Du Pont, 308 U.S. 488, 495 (1940); see generally 4 MERTENs, FEDERAI Income TAXation, $\$ 25.09$ (rev.ed. 1954).

24 See text at note 17 supra.

25 Washburn v. Counmissioner, 5 T.C. 1333 (1945) and McDermott v. Commissioner, 150 F.2d 585 (D.C. Cir. 1945), are mentioned in the Senate Finance Counmittee Report. 83d Cong., 2d Sess., 3 U.S. Code Cong. \& Admin. News 4629, 4813 (1954). But see Robertson v. Commis- 
Under the new statutory provisions of the 1954 Code, the general rule includes in gross income all amounts received as prizes or awards. Section 74(b) provides an exception for prizes and awards which meet a three-fold test. ${ }^{20}$ If such prize or award is (1) given primarily in recognition of past achievements in religious, charitable, scientific, educational, artistic, literary or civic fields; and (2) the recipient was selected without any action on his part; and (3) the recipient is not required to render substantial services as a condition for receiving it, it is excluded from gross income. The first test makes the exclusion provision inapplicable to television and other advertising prizes and give-aways. ${ }^{2 \pi}$ The second test makes all contest prizes includible in gross income and thus overrules by legislation McDermott $v$. Commissioner ${ }^{28}$ which had held the Ross Essay Prize of the American Bar Association excludible from gross income under the 1939 Code. The last test seems to draw the he between prizes and awards on the one hand and payment for future services ${ }^{29}$ as well as scholarships and fellowships on the other. The importance of distinguishing awards and prizes from scholarships and fellowships is indicated by the wording of the statute ${ }^{30}$ and of the regulations under it. ${ }^{31}$ This distinction will be discussed hereafter because it goes to the definition of scholarships and fellowships within the meaning of section 117.

\section{THE TAXATION OF SCHOLARSHIPS AND FELLOWSHIPS}

The tax treatment of scholarships and fellowships is regulated by statute for the first time in section 117 of the 1954 Code..$^{32}$ Under prior law, the question of whether such stipends could be excluded from gross income depended primarily on whether they could be classified as gifts. ${ }^{33}$

sioner, 343 U.S. 711 (1952), which fully sustains the Commissioner's position in these contest cases under the INT. REv. Code of 1939. See also United States v. Amerikian, 197 F.2d 442 (4th Cir. 1952) ; Stein v. Commissioner, 14 T.C. 494 (1950); Waugh v. Commissioner, 9 CCH Tax Ct. Meln. 309 (1950); 40 CALIF. L. Rev. 612 (1952).

26 See also U.S. Treas. Reg. $\$ 1.74-1$ (b) ; Rev. Rul. 57-19, 1957 Int. REv. BuzL. No. 3, at 7.

27 The extent to which such give-aways may still be excluded from gross income under section 102 (a) of the 1954 Code as gifts is not within the scope of the present inquiry.

28150 F.2d 585 (D.C. Cir. 1945).

29 See, e.g., Strauss v. Commissioner, 6 CCH Tax Ct. Mem. 830 (1947), whcre the intent of the award was recognition of past charitable and scientific work, but the formalities were so awkwardly handled as to make it appear that the award was for future services and the formalities were held to govern the tax result.

30 INT. REv. CODE of 1954, \& 74(a).

31 U.S. Treas. Reg. $\$ 1.74-1$ (c).

32 See generally Oliver, Treatment of Fellowship Grants under the Federal Income Tax, 43 AM. Ass's Untv. Prof. Butc. 65 (1957).

${ }^{33}$ See generally Huherman, Scholarships, Fellowships and Frizes, 3 Hastnas L.J. 116 (1952); Note: Scholarships, Fellowships and Prizes: Gift or Income?, 38 MnNo. L. REv. 152 (1954). 
The new statutory provision, although in itself quite complex, will undoubtedly clarify this area of the law; but it has also put a quantitative limitation on the excludibility of certain scholarships and fellowships, primarily post-doctoral grants, which was not present under the prior law once the payment could be classified as a gift.

Under the general rule of section 117 of the 1954 Code, all amounts received as scholarships or fellowship grants and all amounts received to cover expenses incidental to such scholarships or fellowship grants, and actually so expended, are excludible from gross income. ${ }^{34}$ However, there are also certain limitations imposed by this section. If the recipient is a candidate for a degree at an educational institution meeting the requirements of section 151 (e) (4),$^{35}$ le cannot exclude that portion of the scholarship or fellowship grant which is compensation for part-time teaching, research or other similar activity, though such activity be a condition to the award of the scholarship, unless such part-time research, teaching or other activity is required by the curriculum for all candidates for that degree. ${ }^{30}$

If the recipient is not a candidate for a degree, ${ }^{37}$ the payments are still excludible from gross income, if the grantor is either a governmental agency or a tax exempt private organization as defined in section 501(c) (3); but there is a quantitative limitation whereby the recipient can exclude only an amount equal to $\$ 300$ times the number of months for which the grant is given..$^{38}$ No further exclusion is allowed after the individual has excluded amounts as scholarships or fellowship grants, while not a candidate for a degree, for 36 months, whether or not consecutive.

The Treasury has ruled that where a granting institution adds an allowance for dependents to the grant, the total amount received is subject to section 117 and its limitations on excludibility; the fact that such an added allowance is made does not enlarge the excludible amount under section 117 (b) (2)(B)..$^{38}$

${ }^{34}$ INT. REv. CODE OF 1954, §117(a).

35 This means an "educational institution which normally maintains a regular faculty and curriculum and normally has a regularly organized hody of students in attendance at the place where its educational activities are carried on." INr. REv. CoDE of 1954, \$151(e) (4). A correspondence school, for instance, would not qualify.

36 INT. REv. CODE OF 1954, \$117(b) (1).

37 As the term "candidate for degree" is used for the purposes of INT. REV. CODE or 1954, $\S 117$ (b) (1).

38 As to the mechanics see U.S. Treas. Reg. $\$ 1.117-2$ (b) (3) examples (1) and (2). It should at least be mentioned that even this quantitative limitation finally enacted is more favorable than the original version of the House bill which would have entirely excluded from the benefits of $\S 117$ post-doctoral grants which exceed in amount $75 \%$ of the salary earned by the recipient in the preceding year. H. REP. No. 1337, 83rd Cong., 2d Sess. (1954). See, e.g., the pay range for post-doctoral and semior post-doctoral fellowships of the National Science Foundation. 45 C.F.R. $\$ \S 602.6,603.6$ (Supp. 1956).

${ }^{39}$ Rev. Rul. 55-554, 1955-2 CuMr. BuLL. 36. 
The new statutory provision raises many new problems. The first question which must be answered under this new section is this: What is a scholarship or fellowship grant within the meaning of section 117? The statute gives no definition, but according to the regulations ${ }^{40}$ scholarships are amounts paid to a student to aid him in pursuing his studies; and fellowship grants are amounts paid to aid an individual in the pursuit of study or research. That these definitions will not be very helpful becomes immediately apparent if one explores the borderline between these new statutory concepts on the one hand and payments for services, gifts, prizes, and awards on the other.

Because of the many and varied forms in which stipends for research or study are given today, it will often be hard to distinguish scholarships and fellowship grants from salaries. The regulations ${ }^{41}$ have made an effort to provide a guiding hine in this respect which goes to the very definition of these new statutory concepts. An example will point out the difficulty.

$\mathrm{Mr} . \mathrm{Z}$ is a graduate student in a physics department working for his doctoral degree. The institution receives grants froin the federal government to do nuclear research and in turn employs its graduate students to help in this task. After some time, $\mathrm{Z}$ and other graduate students are assigned research projects which are not only part of the governmental research program but also will serve as doctoral theses for these students. Are the amounts received by $Z$ while working on what will be his doctoral thesis scholarships or fellowship grants? If they are, do they come within the limitation of section 117 (b) (1) as compensation for services? The latter question must be answered in the negative, since research of the type done by $\mathrm{Z}$ is required of all candidates for the $\mathrm{Ph} . \mathrm{D}$. degree whether or not they receive grants. Thus the first question is the decisive one, because unless the amounts paid can be properly defined as scholarships or fellowship grants, section 117 cannot apply at all. Under the test given by the regnlation $\mathrm{s}^{42}$ the question of grant or salary is whether the primary purpose of the research or study is to further the education and training of the recipient in lis individual capacity or whether the primary purpose is to benefit the grantor. This test had already been hinted at in a Tax Court decision under pre-1954 law which ruled against the taxpayer on facts very similar to the example here. ${ }^{43}$

There is little doubt that the Commissioner will deny Z's claim to the benefits of section 117 and will rule that the payments are salary for ser-

40 U.S. Treas. Reg. \$§ 1.117-3(a), (c).

41 Id. $\S 1.117-4$ (c).

42 Ibid.

43 Banks v. Commissioner, 17 T.C. 1386 (1952); cf. Ti Li Loo v. Commissioner, 22 T.C. 220 (1954). 
vices. ${ }^{44}$ This test relating the work done under the grant to the purposes of the grantor will be applied regardless of whether the recipient is a candidate for a degree, since no part of section 117 can apply unless it is met. ${ }^{45}$

If this test is applied in a manner which shows appreciation for the circumstances under which scholarships and fellowships are given, section 117 will have a liberalizing effect for taxpayers of this deserving group. The decisions under the pre-1954 law had to contend with a narrow test, namely whether the amount received was a gift. Since scholarships and fellowships are not gifts in the traditional sense, the application of this test brought very unsatisfactory results. ${ }^{46}$

The new test supplied by the new concepts of section 117 allows a more realistic appraisal of the situation. ${ }^{47}$ In determining the distinction between scholarships or fellowship grants on the one hand and compensation for services on the other, a number of factors of differing relevancy must be considered.

Many scholarships and fellowships are given on the condition that the recipient devote full time to his studies or research. This element is therefore irrelevant in distinguishing payments under section 117 from compensation for services. ${ }^{48}$ But another factor which has been considered decisive, ${ }^{49}$ the fact that the university may retain certain rights in the research product of the recipient of the stipend, is undoubtedly still a point which must be considered. But other factors may neutralize this condition for the purpose of the inquiry here, for example, that the university makes available to the research fellow laboratory facilities, an office, equipment and other similar necessities.

Finally, the view taken by the dissenting judges in Stone v. Commissioner $^{50}$ that a foundation, established to advance the arts, knowledge, and science generally, makes something amounting to a bargain and purchase when it gives a grant to a professor to enable hin to write a book on the English theatre between 1660 and 1800, even though the foundation will have no rights in the manuscript, betrays a complete lack of understanding of the realities of such situations.

44 See Rev. Rul. 56-101, 1956-1 Cum. Burx. 89; Rev. Rul. 56-419, 1956 InT. Rev. Burx. No. 35 , at 9 .

45 Rev. Rul. 56-101, sutpra note 44; cf. Rev. Rul. 57-131, 1957 INT. Rev. Buxx. No 14, at 6.

46 See Doerge v. Commissioner, 11 CCH Tax Ct. Mem. 475 (1952); I.T. 4056, 1951-2 Curr. BuLz. 8; see also the dissent of five judges in Stone v. Commissioner, 23 T.C. 254, 265 (1954).

47 See Rev. Rul. 56-419, 1956 Ivr. Rev. Buxc. No. 35, at 9.

48 The opinion in Doerge v. Commissioner, $11 \mathrm{CCH}$ Tax Ct. Mem. 475 (1952), shows error of reasoning even under pre-1954 law by attaching weight to this point.

49 Doerge v. Commissioner, supra note 48 . The absence of this factor does not necessarily aid the taxpayers. I.T. 4056, 1951-2 CuM. BULI. 8.

5023 T.C. 254, 265 (1954). 
Exploring further the often elusive borderline between fellowslips and payment for services, let us consider the post-doctoral Fullbright ${ }^{\text {t1 }}$ fellow who is sent, for the period of an academic year, to a university abroad as a guest professor. He is paid in local currency the equivalent of the salary of a professor at the university where he will lecture and in addition receives amounts to cover transportation. ${ }^{62}$ Even though the amounts paid in local currency are superficially like a salary for teaching, it should be clear that they are received as fellowship grants within the meaning of section 117. The Government itself las set up the disbursenient of these funds in the form of a large-scale scholarship and fellowship program under the Fullbriglt amendment to the Surplus Property Act of 1944. It makes these grants not because it bargains for the specific activity of the individual recipient, but because of the beneficial effect in terms of the advancement of learning, exchange of ideas and fostering of friendly relations with other countries which results fron the operation of the program as a whole. This seems to be the decisive elenent which establishes such payments as scliolarships or fellowship grants within the meaning of section $117 .^{.3}$

The regulations ${ }^{54}$ differentiate from scholarships and fellowship grants not only payments which are compensation for present services but also anlounts received in consideration for past or future services. It would be difficult to argue that the continued salary paid to a professor during his sabbatical leave is not taxable income; it is part of the total consideration which he receives for his services as a faculty meniber. But in a situation such as was referred to earlier in the discussion of the deductibility of educational expenses ${ }^{55}$ the problem is different. A private secondary school feels that its teachers will benefit so greatly from study trips abroad that it gives them "leave of absence with pay" to undertake such trips. Could these amounts be deenied fellowships? The answer would depend on several factors. If it is in the nature of a sabbatical leave, that is, if the teachers are entitled to leave with pay after a given number of years of teaching at the school, it cannot be a fellowship. If the teacher is obligated, after taking such leave, to return to the institution for further teaching, it is not a fellowship. In the first instance the leave-pay is for past services rendered,

$\mathbf{5 1}$ The funds are made available through sale of surplus government property located aboard. 50 U.S.C. App. § 1641 (Supp. 1956).

52 It seems clear that this taxpayer cannot escape taxation by invoking INT. REv. CODE or 1954, \$ 911, since the real source of the payments is the United States Government, and also because he will not qualify as a foreign resident.

53 But see U.S. Treas. Reg. $\$ \$ 301.6316-1-301.6316-8$, which provides for paynient of income tax in foreign currency by Fullbright-fellows and which seems to assume that amounts received under such grants could be includible im gross income in their entirety.

54 U.S. Treas. Reg. 1.117-4(c) (1).

55 Rev. Rul. 55-412, 1955-1 CuM. Burl. 318. See text at note 17 sitpra. 
while in the latter situation it is advance compensation for services to be rendered in the future. If neither is the case ${ }^{56}$ and if the travel project on which the grant is conditioned is one designed to further the education and training of the recipient in his individual capacity, it is difficult to see why these payments should not be deemed fellowships within the meaming of section 117. The fact that the added learning and experience of the teacher will redound to the benefit of the school which makes the grant, if the teacher returns to his former position, should not deprive these payments of their character as fellowship grants.

The factual situations here discussed cannot possibly exhaust the problems which will arise in the search for the borderline which separates scholarships and fellowship grants from payment for services, past, present, or future. It will take a greater understanding of the realities of academic life to reach just results than has hitherto been shown by the Internal Revenue Service and the courts.

The next complex of problems is raised by the necessity of distinguishing between scholarships and fellowship grants on one hand and awards and prizes under section $74(\mathrm{~b})$ of the 1954 Code and gifts on the other hand.

The express reference to section 117 in section 74 indicates the possibility of overlap. The regulations ${ }^{57}$ make it clear that once a grant is deemed subject to section 117 , and therefore excludible at least in part, the portion which could not be excluded under section 117 cannot be excluded as a gift or as a prize or award. But this would not foreclose the argument that a particular amount received by a taxpayer is entirely a gift or a prize or award rather than a scholarship or fellowship grant; when the receipts exceed the excludible amounts under section 117, the argument may seem worthwhile to the taxpayer.

Under the terms of most scholarships or fellowships the question cannot arise as far as prizes and awards under section 74(b) are concerned because normally interested and qualified persons must make application for them. Section 74(b) operates to exclude from income certain prizes and awards if the amounts received came to the individual without any action on his part. But there are post-doctoral research grants which are offered to individuals selected without any participation or application on their part and who remain ignorant of the fact that their name is even being

56 We assume that the school is a private tax exempt institution under $\$ 501(c)(3)$ and therefore qualifies under $\S 117$ (b) (2). Certainly the fact that the granting institution is also the employer of the recipient would not of itself disqualify these payments from partaking of the benefits of $\$ 117$. See Oliver, Treatment of Fellowship Grants under the Federal Income Tax, 43 Aar. Ass'n Unrv. Prof. BuLd. 65, 68 (1957).

67 U.S. Treas. Reg. \$ 1.117-(1) (a). 
considered until the grant is offered to them. The selection is made entirely on the basis of the past record of achievements of the individual. If, in addition, the recipient is left entirely free to decide what to do with the grant, that is, if there are no specific conditions relating to designated research projects, reports to the granting institution, or similar requirements which are common conditions to fellowships or scholarships, there may be a genuine question whether such amounts do not come within the exclusionary provisions of section $74(\mathrm{~b})$.

The answer can be found only by considering the every-day meaming of the words "fellowship grant" and "prize." The former implies a giving to further learning and scholarly endeavor, the latter is a gift in recognition of past achievement. The fact that the recipient is selected on the basis of his past record of achievements does not mean that the grant is made to reward hin for them, but may and is more likely to mean that the donor expects future achievements, with the help of this grant, because this is a well-founded hope considering the recipient's past record. The absence of any conditions inay be explained by the reasonable expectation of the donor that the recipient will apply the funds in a nanner which meets the purposes of the donor without their necessity. Thus, if the motive of the donor is carefully considered, it should not be hard to distingnish scholarships and fellowship grants froin prizes and awards.

The problems in distinguishing between gifts, excludible under section 102, and scholarships and fellowships within the meaning of section 117 are somewhat different. The regulations tell us that if an individual gives money to a family member, friend or any other individual to help him pursue his studies, the amount so received is not a fellowship or scholarship under section $117 .^{58}$ The question is probably unimportant because such payments, if not under section 117 , are gifts and excludible under section $102 . .^{59}$ But the regulations are probably correct because such individual gifts are not within the common ineaning of the terms "scholarships" or "fellowships." Beyond this, the argument, fortified by cases under the pre$1954 \mathrm{law}^{60}$ that fellowships and scholarships may be gifts for purposes of incoine taxation must be answered by the well-established rule of statutory construction whereby the inore specific provision, here section 117, governs over the more general one, here section 102. Thus, under the 1954 Code, if a grant to an individual is a scholarship or fellowship within the meaning of section 117 , the argument that such amounts were received as a gift under section 102 is foreclosed.

58 U.S. Treas. Reg. $\$ \S 1.117-3(a)$, (b).

59 Of course, an individual would not in any event be a qualified donor of payments to persons who are not candidates for a degree. INT. REv. CoDE of 1954, $\$ 117$ (b) (2) (A); to the donor the classification would be irrelevant since he cannot take a deduction in either case.

60 See authorities cited at note 33 supra. 
There is no doubt that the most difficult problems in the practical application of section 117 will arise in the areas just discussed, having to do with the definition of the term "scholarships" and "fellowship grants" as used in this new section. But there are other problems to be considered.

The source of the grant becones of special importance for persons who are not candidates for a degree. The recipient of such a stipend cannot claim the benefits of section 117 unless the grantor is a governmental agency or a private tax exempt institution as defined in section 501 (c) (3)..$^{\text {or }}$ This means that if a labor union which is tax exenpt under section 501(c) (5) or a Chamber of Commerce which is tax exempt under section 501 (c) (6) makes a post-doctoral research grant, the recipient could not clann the benefits of section $117 .^{62}$ It is therefore advisable that whenever an organization not within section 501(c)(3) wishes to make a genuine fellowship grant to a person not a candidate for a degree, this be done by channelling the gift through a qualified institution such as a university. If the university is then also charged with the selection of the recipient, and if the grant is not conditioned on the recipient doing research work which is specified in detail by the original donor of the fund, the amounts received partake of the benefits of section 117 and are not payment for services. Although the committee reports do not mention this, Congress probably intended by this himitation to aid in distinguishing between fellowships and payments for services, a distinction more difficult where the recipient of the payments is not a candidate for a degree. Such tax exempt groups as may, for instance, come under section 501 (c) (6) or (7) pursue their own policies and purposes, representing various economic and other group interests; grants made by such organizations for research would probably im any event be more often payment for services than fellowships. By disqualifying all but those tax exempt groups which have traditionally been the administrators and disbursers of scholarship and fellowship programs, Congress has barred any attenipts by other groups to bring their disbursements for research under section 117 .

As imdicated earlier, it is not the purpose of this Article to elaborate on the mechanics of section 117 , conplex as these may be. They are set out in the regulations. However, the regulations do not give an answer to all prob-

01 Section 501 (c) (3) lists the following organizations: "Corporations, and any community chest, fund, or foundation, organized and operated exclusively for religious, charitable, scientific, testing for public safety, hiterary, or educational purposes, or for the prevention of cruelty to children or animals, no part of the net earnings of which inures to the benefit of any private shareholder or individual, no substantial part of the activities of which is carrying on propaganda, or otherwise attempting, to influence legislation, and which does not participate in, intervene in (including the publishing or distribution of statements), any political canjpaign on behalf of any candidate for public office."

02 The question would then be whether the payenent can be classified as a gift. 
lems. Let us assume that a taxpayer, an eminent professor of sociology, receives a post-doctoral grant from a qualified foundation to study the social institutions of some remote and primitive tribe. He receives a total of $\$ 12,000$ for one year and he incurs expenses for transportation and other travel costs in the amount of $\$ 6,000$. In the first part of this Article it has been shown that these expenses are deductible as the ordinary and necessary expenses of a scholar. Since only a portion of the amount received is to be included in gross imcome, deductible expenses incurred in connection with the fellowship grant should probably be allocated in the same ratio to excludible and includible portions of the grant..$^{03}$ However, the regulations are silent on this problem, and a taxpayer would certainly be entitled to see first whether it would be improper to deduct the entire amount of the expense. The whole problem is avoided quite simply if the donor institution makes an estimate of the expenses and expressly designates a portion of the grant to cover these expenses. ${ }^{64}$ Amounts so designated to cover expenses, and actually so expended, are excludible under section 117 (a) (2) and the quantitative limitation in section $117(b)(2)(B)$, which allows the exclusion to persons who are not candidates for a degree only up to $\$ 300$ times the number of months covered by the grant, does not apply to such expenses. ${ }^{65}$ Whether the second limitation of section 117 (b) (2)(B), ${ }^{\text {CB }}$ which denies the exclusion after the taxpayer has had the benefits of section 117 for 36 months, ${ }^{67}$ applies to expenses excludible under section 117 (a) (2) is not clear. The statutory language seems to mean that if a taxpayer who is not a candidate for a degree has excluded scholarships and fellowship grants under section 117 (a) (1) for 36 months, he can thereafter exclude neither further grants nor amounts expressly desiguated to cover expenses and actually so expended. But any month for which the taxpayer merely received such expense amounts excludible under section 117 (a) (2) does not count to make up the total of 36 months after which further exclusions are denied.

63 If the grant runs from January 1 to December 31, our professor will exclude $\$ 3600$ under $\S 117$ and include $\$ 8400$. If the rule here suggested were followed, taxpayer could take a deduction for $\$ 4200$.

64 The regulations, U.S. Treas. Reg. $\$ 1.117-1$ (b) (1) require a specific designation of such amounts as intended to cover expenses incident to the scholarship or fellowship grant.

65 Thus if in the example $\$ 6,000$ had been expressly designated to cover expenses, and had actually been so expended, taxpayer of course would have no deduction, but would merely include $\$ 2,400$ of the total of $\$ 12,000$ in his gross income, and then would still have his optional $10 \%$ standard deduction.

${ }^{66}$ Also applicable only to persons who are not candidates for a degree. degree.

67 I.e., has excluded amounts under $\$ 117$ which he received while not a candidate for a 


\section{CONCLUSTON}

The great difficulty encountered in writing on problems in the area herein discussed lies in the dearth of case law. Scholars are not litigious, and if they wanted to be, they could hardly afford it. Thus perhaps the writer here has fought some windmills in the course of his argumentation. But if the existing precedent was correctly evaluated, there is no doubt that the deep cleavage between those within and those without the ivory tower has, in this instance, redounded greatly to the detriment of those within. The tax collector, clearly, is ante portas.

The discussion of the tax treatment of expenses of scholars clearly shows that no more is needed to obtain just results than a recognition of the fact that our college and university instructors and professors are expected to be more than lecture note reproduction machines. Independent research and study in the specific field of each individual is an integral part of his duties, and the expenses incidental thereto are the ordinary and necessary expenses of his chosen profession. Once this fact is acknowledged, the statute means for the scholar exactly what it means for the busmessman. That there are, in addition, the strongest considerations of public policy in favor of allowing the deduction of such research and study expenses hardly needs mention.

With regard to the other two areas of the law here discussed, the new statutory regulation of prizes and awards will not create many problems in its practical apphication. The new statutory regulation of scholarships and fellowships, on the other hand, will cause some difficulty due to the wide variety of grants for scholarly purposes which are available today. However, there is no doubt that section 117 can fully perform its function of clarifying a fonnerly confused area of the revenue laws if it is applied with a keen understanding of academic life and of the operation of those tax exempt foundations which today disburse a substantial part of the funds which oil the wheels of scholarly enterprise in this country. 


\section{California Law Review}

JNENGER NATIONAL AND WESTERN CONEERENCES OF LAW REVIEWS

Published Five Times Yearly by Students of the School of Law of the University of California, Berkeley, California. Indexed in Index to Legal Periodicals and Public Affairs Information Service.

\section{BOARD OF EDITORS \\ Donald M. Caenen \\ Editor}

Watrace R. Pece

Assistatt Editor

Writrayr R. Berraran Managing Editor

GeraId R. KNEcht

Robert O. NaGLe

Robert A. Selicson

W. P. Crancey, Jr.

BIIIY H. HuNT

Donatd L. Knge

Marshatr W. Krause
Marc H. Moneranme Article Editor

JOE J. YASAKI

Book Review Editor

Revising Editors

Johr E. SPARES

Stanton G. WABE

Associate Editors

Harold E. LaNdis

RICHARD T. LEXSMON

Wintrazr O. Mñor

Roger J. Nichols

Marifyn LINDQUIST

General Secretary

Contributors

Arteur O. ArMstrong, Jr.

HaROLD C. NAChTRIEB

Marcolm S. Burnstetn

Edaund L. Regatta

Mrtes A. Cobb

Bruce M. Cowan

Claude D. Rohwer

JaMES H. DAFFER

JaN S. Stevens

PaUL W. HartLOFF, JR.

E. ROBERT WALTaCH 